\title{
The Scottish Colonising Voyages to Carolina and East New Jersey in the 1680s
}

\section{Joseph Wagner}

Cette note de recherche donne un aperçu des seize voyages en Caroline et dans l'est du New Jersey qui ont fait partie des efforts de colonisation écossais dans ces colonies de 1682 à 1688. L'accent est mis sur les navires, les lieux et les dates de leurs départs, leurs cargaisons et le nombre de passagers qu'ils transportaient. Ces renseignements comblent les lacunes dans nos connaissances des entreprises coloniales écossaises et illustre la participation des Anglais et des Irlandais à ces entreprises.

\section{Introduction}

Scots undertook two focussed ventures to establish themselves in English colonies in the 1680s - one in Carolina and one in East New Jersey. The Carolina venture was the result of Scottish Presbyterians seeking a retreat from religious persecution in Scotland. They were joined by Scottish merchants hoping to establish a transatlantic trade not subject to the English Navigation Acts, which restricted Scottish trade with English colonies. The attempt to establish a Scottish settlement in Carolina began in 1682, but was largely ended by the destruction of the Scottish settlement of Stewartstoun (established in 1684) by the Spanish in $1686 .{ }^{1}$ The

\footnotetext{
1 In addition to the sources mentioned in notes 7-9, see Linda G. Fryer, "The Covenanters' Lost Colony in South Carolina," Scottish Archives, 2 (1996), 98-106; Kurt Gingrich, "“That will make Carolina powerful and flourishing': Scots and Huguenots in Carolina in the 1680s," South Carolina Historical Magazine, 110 (January-April 2009), 6-34.
}

The Northern Mariner / Le marin du nord, XXX, No. 2 (Summer 2020), 155-166 
East Jersey venture was overseen by the Scottish Quaker Robert Barclay of Ury and saw additional Scots join the project for commercial, religious, social, and national reasons. Interest in the project in Scotland was at its height from 1683 to 1688 . Though interest in Scotland waned in the subsequent years, Scots in the colony continued to be influential in its development. ${ }^{2}$ Historians have identified and discussed several ways in which these colonial ventures are important to Scottish history. For example, it has been argued that they were expressions of Scottish independence and sovereignty, that they were precursors to the boom in Scotland's transatlantic trade in the eighteenth century, and that they saw an important movement of people and ideas from Scotland to America. ${ }^{3}$

One area that historians have run into difficulty is providing an account of the vessels and settlers that made the transatlantic journey to the colonies. For example, George Pratt Insh's seminal account mentions several Scottish voyages to East Jersey, but only provides the name and details of one of the vessels used. ${ }^{4}$ John Pomfret's excellent study of East Jersey adds a detailed account of a second vessel, but not of the others to which he refers vaguely and speculatively. ${ }^{5}$ Ned Landsman does not provide many additional details relating to the voyages, but, unlike Insh and Pomfret, he provides an estimate of the number of settlers transported by the Scots. He suggests that 700 people were transported, but does not explain how exactly that figure was reached. ${ }^{6}$ Regarding the Scottish efforts to establish a settlement in Carolina, Insh only mentioned two voyages to the colony and only named one vessel. ${ }^{7}$ Recent studies have filled many gaps in our knowledge of the Carolina voyages, but a clear and comprehensive account has remained elusive. ${ }^{8}$ Peter Moore has recently suggested that "historians on both sides of the Atlantic

2 In addition to the sources mentioned in notes 4-6, see Ned Landsman, "William Penn's Scottish Counterparts: The Quakers of 'North Britain' and the Colonization of East New Jersey," in Richard S. Dunn and Mary Maples Dunn, eds., The World of William Penn (Philadelphia: University of Pennsylvania Press, 1986), 241-257; Linda G. Fryer, "Robert Barclay of Ury and East New Jersey," Northern Scotland, 15 (May 1995), 1-17.

3 T. M. Devine, Scotland's Empire and the Shaping of the Americas, 1600-1815 (Washington, D.C.: Smithsonian Books, 2003), 4, 36-40; Allan I. Macinnes, Union and Empire: The Making of the United Kingdom in 1707 (Cambridge: Cambridge University Press, 2007), 164-171; Kurt Gingrich, "“To Erect a Collonie of Scottish Subjects in Aney Pairt of America': The Quest for a Scottish Colony in North America in the 1680s," Journal of Early American History, 2 (2012), 68-98.

4 George Pratt Insh, Scottish Colonial Schemes, 1620-1686 (Glasgow: MacLehose, Jackson \& Co., 1922), 163-179.

5 John E. Pomfret, The Province of East New Jersey, 1609- 1702: The Rebellious Proprietary (Princeton: Princeton University Press, 1962), 186-198.

6 Ned C. Landsman, Scotland and its First American Colony, 1683-1765 (Princeton: Princeton University Press, 1985), 113-114, 269.

7 Insh, Scottish Colonial Schemes, chap. 6.

8 See, for example, L. H. Roper, Conceiving Carolina: Proprietors, Planters, and Plots, $1662-$ 1729 (Basingstoke: Palgrave Macmillan, 2004), 78-89; Tom Barclay and Eric J. Graham, The Early Transatlantic Trade of Ayr, 1640-1730 (Ayr: Ayshire Archaeological and Natural History Society, 2005), 32-37; David Dobson, Scottish Trade with Colonial Charleston, 1683 to 1783 (Glasgow: Humming Earth, 2009), 16, 115-118, 165-166. 
have failed to appreciate the significance of Stuarts Town, Scotland's short-lived colony in Port Royal, South Carolina." As in the case of histories of the East Jersey venture, his article on the topic would have done more to demonstrate the significance of Scottish colonisation if more information on the number of voyages and settlers was provided.

The aim of this research note is to offer a more complete account of the Scottish colonising voyages to Carolina and East Jersey in the 1680s than hitherto provided. This account makes use of previously overlooked sources and corrects some misapprehensions found in previous accounts. With a clear and well evidenced account of the vessels and approximate numbers of passengers that sailed to Carolina and East Jersey under Scottish auspices, the foundation is laid for an updated analysis of the ventures in their broader contexts. For example, the use of English vessels in the expeditions to East Jersey suggest "British" cooperation in the venture while the English Navigation Acts prohibited Scottish vessels and crews from trade with English colonies; Scottish commercial and confessional networks in Ireland are implied by the fact four vessels with Scottish links sailed to Carolina via Ireland; and we learn that the scale of the Carolina venture was larger than previously thought, indicating greater interest in the project than historians have suggested.

\section{Carolina}

The first vessel sent from Scotland to Carolina as part of the colonising venture was the 50-ton James of Irvine, which set sail from Glasgow around 16 October 1682 loaded with "goods to the valow of two hundreth pound ster[ling] in name of S[i]r Jo[h]n Cochrane and S[i]r George Campble and the rest of the partiners of the Carolina Company." ${ }^{10}$ As seen here, the goods were sent on the account of the Scottish Carolina Company, which had chartered the vessel with the aim of testing the trading waters and reconnoitring the colony for the best place to settle. The James was owned by the prominent Glasgow merchant Walter Gibson and commanded by his infamous brother James Gibson. ${ }^{11}$ After a stop in Bermuda, the vessel arrived at Charles Town around 3 March 1683. The company's agents sold their cargo and gathered information about the colony, concluding Port Royal was the best region to settle. The James arrived back in Scotland around July $1683 .^{12}$ There is no evidence of Scots settling in Carolina as part of this expedition.

The plans of the Carolina Company were disrupted by the discovery of

9 Peter N. Moore, "Scotland's Lost Colony Found: Rediscovering Stuarts Town, 1682-1688," Scottish Historical Review, 99 (April 2020), 26.

10 Port Glasgow entry book: exports, 16 October 1682, fol. 24, National Records of Scotland (NRS), E72/19/6.

11 Linda G. Fryer, "Documents Relating to the Formation of the Carolina Company in Scotland, 1682," South Carolina Historical Magazine, 99 (April 1998), 110-134.

12 John Crawford, A New and Most Exact Account Of the Fertiles[t] and Famous Colony of Carolina (Dublin, 1683), 3-7. 
the Rye House Plot in 1683 as several members, including the leading figures Sir George Campbell of Cessnock and Sir John Cochrane of Ochiltree were implicated. ${ }^{13}$ Nonetheless, the Carolina venture was continued under the leadership of William Dunlop (who would later become principal of Glasgow University) and the persecuted nobleman Henry Erskine, $3^{\text {rd }}$ Lord Cardross. They oversaw the expedition of the 170-ton Carolina Merchant (formerly the Pelican) of Glasgow to Carolina in 1684. The Carolina Merchant, like the James of Irvine, was owned by Walter Gibson and again James Gibson was the master. Walter Gibson and William Dunlop acquired thirty-six prisoners, mostly Presbyterian rebels, from the Scottish privy council to be sent to the colony and a total of 148 emigrants went to the colony on the vessel..$^{14}$ It appears that fourteen servants were transported on Walter Gibson's account, seventeen were transported on Cardross' account, and twentytwo were transported on Dunlop's account.$^{15}$ Cardross and Dunlop were the most prominent individuals who made the journey, but they were accompanied by at least one other landed gentleman: the persecuted Ayrshire laird John Montgomerie of Crevock. ${ }^{16}$

The Carolina Merchant departed Gourock on 21 July 1684 with a cargo that included textiles, clothing, and buttons. ${ }^{17}$ It arrived at Charles Town on 2 October with all passengers surviving the journey, but the prisoners had been ill-treated and many became ill (or were already ill) and died after their arrival. ${ }^{18}$ Others deserted and some servants intended for the Scottish settlement of Stewartstoun were instead sold at Charles Town. The deaths and desertions resulted in only forty-nine individuals accompanying Cardross and Dunlop to establish Stewartstoun. ${ }^{19}$

Three less known voyages with some connection to Cardross and Dunlop set sail for Carolina around the same time. First is that of the Scottish merchant Robert Malloch, who competed with Walter Gibson to acquire prisoners from the privy council to send to the colony. ${ }^{20}$ The Carolina Company member George Clerk

13 Roper, Conceiving Carolina, 74-82.

14 P. Hume Brown, Henry Paton, and E. Balfour-Melville, eds., The Register of the Privy Council of Scotland (RPCS), $3^{\text {rd }}$ ser., 16 vols. (Edinburgh: H. M. General Register House, 1908-1970), 8: 710711, 9: 208; Cardross and Dunlop to Sir Peter Colleton, 27 March 1685, fol. 16r, National Library of Scotland (NLS), MS.9250.

15 Sue Mowat and Eric J. Graham, eds., Records of the Scottish High Court of Admiralty, 16271750 (RSHCA), CD-ROM (Edinburgh: Early Scottish Maritime History, 2005), AC7/8, 15 April 1687; A. S. Salley, ed., Warrants for Lands in South Carolina, 1680-1692 (Columbia, SC: Historical Commission of South Carolina, 1911), 179.

16 Montgomerie was accompanied by his son and died in the colony. RPCS, $3^{\text {rd }}$ ser., 10: 156-157; Walter MacLeod, ed., Journal of the Hon. John Erskine of Carnock, 1683-1687 (Edinburgh: Scottish History Society, 1893), 72; Dunlop to Sir James Montgomerie of Skelmorlie, 15 July 1686, NRS, GD3/5/774.

17 Port Glasgow entry book: exports, 1 July 1684, fol. 19, NRS, E72/19/9; MacLeod, Journal, 7172.

18 Cardross and Dunlop to Colleton, fol. 16r, NLS, MS.9250; "The Account of [the] Carolina Voyage," fols. 223r-224v, NLS, Wod.Qu. XXXVI; MacLeod, Journal, 139.

19 Cardross and Dunlop to Colleton, fol. 16r, NLS, MS.9250.

$20 \quad R P C S, 3^{\text {rd }}$ ser., 8: 525-527, 9: 15-16, 28-31, 69-70, 95-96, 100-102, 111, 115. 
contributed $£ 950$ Scots (about $£ 79$ sterling) to the voyage. ${ }^{21}$ They sailed on the Alexander of Inverkeithing, master Thomas Thompson, from Leith on 14 August with a cargo that included shoes and linen cloth. ${ }^{22}$ Cardross' half-brother, John Erskine of Carnock, noted that Malloch set sail with "about 150 persons he had got a gift of" and Malloch received 3,700 acres of headland for transporting seventyfour servants after their arrival in Carolina in November. ${ }^{23}$ It is likely that Cardross and Dunlop were referring to those transported on the Alexander when they wrote of "our countriemen who designed to setle w[i]th us, arrived in ane uy[e]r veshell from Scotland" who were discouraged from settling in Stewartstoun "by thos about Charilstoun who had litle kyndes to us." 24

The other two vessels did not make it to Carolina and had not sailed directly from Scotland. These were the Charles of Glasgow, which sailed from Glasgow via Ireland (perhaps Belfast), and the 120-ton James of Ayr, which sailed from Ayr via Belfast. Interest in Carolina among Presbyterian dissenters in Ulster had been noted after the discovery of the Rye House Plot in 1683 and again in January 1684 by William Stewart, $1^{\text {st }}$ Viscount Mountjoy. ${ }^{25}$ It is fair to surmise that the "divers families removeing from the north of Ireland to Carolina" in 1684 consisted of those dissenters. This idea is supported by the fact that territory in the colony had been secured for them by "Mr Thomas Ferguson," who was likely the dissenting Ayrshire laird Thomas Ferguson of Finnarts, who fled to County Antrim in 1681 or 1682 after being sentenced to death for supporting rebellion in Scotland. ${ }^{26}$ The James, master David Ferguson, departed Ayr around 19 August with a cargo that included textiles, clothing, pipes, knives, buttons, and brandy. ${ }^{27}$ The Charles, master John Murray, departed Glasgow around 29 August with a cargo that included textiles, clothing, buttons, and coal..$^{28}$

Some of the goods carried by these vessels were likely sold in Ireland. According to one account, approximately 140 passengers embarked on the James in Ireland and half of them perished when it wrecked off the coast of Carolina. ${ }^{29}$ The total number of passengers is not corroborated elsewhere, but other sources confirm that it did wreck and another account states that "upwards of 60 people"

${ }^{21}$ RSHCA, AC7/8, 19 August 1687. Also see Discharge by Isobel Ross, 17 December 1686, NRS, GD172/1585; RSHCA, AC7/9, 24 July 1691.

22 Leith entry book: exports, 6 August 1684, fol. 10, NRS, E72/15/28; MacLeod, Journal, 76.

23 MacLeod, Journal, 76; Salley, Warrants for Lands, 163-164.

24 Cardross and Dunlop to Colleton, fol. 16r, NLS, MS.9250.

25 Historical Manuscripts Commission, Calendar of the Manuscripts of the Marquess of Ormonde, K.P. Preserved at Kilkenny Castle, vol. 7 (London: H. M. Stationery Office, 1912), 59-60, 107, 180181.

26 Carolina Proprietors to Sir Richard Kyrle, 11 July 1684, fol. 19v, The National Archives, Kew, CO 5/288; RPCS, $3^{\text {rd }}$ ser., 7: 268, 497, 8: 452; James Paterson, History of the Counties of Ayr and Wigton, (Edinburgh, 1864), 2: 101-102.

27 Ayr entry book: exports, 19 August 1684, NRS, E72/3/13.

28 Port Glasgow entry book: exports, 28-29 August 1684, fol. 21, NRS, E72/19/9.

29 Patrick Walker, The Life and Prophecies of Mr. Alexander Peden, Late Minister of the Gospel At New Glencue in Galloway (Falkirk, 1810), 51. 
were lost. ${ }^{30}$ Cardross and Dunlop referred to the wreck of the James as "the lose... of a [ship] which came from Belfast filled w[i]th our countriemen who design[e]d to setell w[i]th [us]." ${ }^{31}$ An unknown number of would-be settlers embarked on the Charles and the limited evidence available suggests that it was forced to return to Ireland after setting sail. ${ }^{32}$

Another vessel, the Abercorn, set sail from Ulster for Carolina in 1685. It sailed from Londonderry to the new Scottish county of Port Royal (where Thomas Ferguson had acquired land the previous year), where it arrived in May. It had transported at least thirty settlers, but they became ill and twenty-nine died. Thus, the vessel was unable to take the cargo of timber it acquired in Port Royal to Barbados as planned and, instead, sailed to Maryland. ${ }^{33}$ Dunlop was likely referring to passengers from the Abercorn when he wrote in 1686 that "we were indeed a goodly company where the Irish ship came last year but the greatter part of them are dead." ${ }^{34}$ It is unclear if a vessel reported as arriving in Port Royal in 1685 with about eighty people was the Abercorn or a different vessel. ${ }^{35}$

The last vessel known to have had a connection with the Scottish Carolina venture is the 140-ton Richard and John. It was purchased by two Carolina Company members - Sir James Montgomerie of Skelmorlie and William Ross, $12^{\text {th }}$ Lord Ross - in London in 1685 for $£ 1,600$ sterling..$^{36}$ Dunlop was under the impression it was specifically purchased "to advance the settlement at Port Royall" and supply the settlement with settlers and slaves. Additionally, he and Cardross expected their wives and the newly-appointed sheriff of Port Royal, Alexander Dunlop, to be transported to Stewartstoun on the vessel in $1686 .{ }^{37}$ Alexander Dunlop was on the Richard and John with $£ 15$ sterling to be delivered to Cardross from his wife and a "ball of goods" to be delivered to William Dunlop from his wife when it departed Kelburn on the Clyde estuary on 4 March 1686 with the intention of sailing to Port Royal. It, however, never made it to Carolina. It sailed between Carrickfergus and Dublin before leaving Ireland on 2 April to sail to the Caribbean via the Azores. It arrived in Antigua on 16 May and, rather than moving on to Carolina, stayed at the island until setting sail for Britain on $27 \mathrm{July} .{ }^{38}$ William

30 George Scott of Pitlochie, The Model of the Government Of the Province of East-New-Jersey in America; And Encouragements for such as Designs to be concerned there (Edinburgh, 1685), $210 ; \mathrm{J}$.

D. Marwick, ed., Miscellany of the Scottish Burgh Records Society (Edinburgh, 1881), 77.

31 Cardross and Dunlop to Colleton, fol. 16r, NLS, MS.9250.

32 Walker, The Life and Prophecies, 51.

33 William A. Shaw, ed., Calendar of Treasury Books, 1685-1689 (London: H. M. Stationery Office, 1923), 910 .

34 Dunlop to Sir James Montgomerie of Skelmorlie, [1686], NRS, GD3/5/772.

35 St. Julien Ravenel Childs, Malaria and Colonization in the Carolina Low Country, 1526-1696

(Baltimore: Johns Hopkins Press, 1940), 243.

36 Dunlop to Montgomerie, [1686], NRS, GD3/5/772.

37 Letters from Dunlop to Montgomerie, NRS, GD3/5/772-775.

38 Alexander Dunlop's memorandum book, fols. 2r-[4]v, 95-92 (reverse), University of Michigan, William L. Clements Library, wclmss000628. My thanks to Jack Abernethy for photographing this source for me. 
Dunlop viewed the failure of the Richard and John to reinforce Stewartstoun as a direct cause of the settlement's destruction by the Spanish in August 1686: "all this in all probability wold have been prevented by the coming of that ship, the Spaniard dared not to have come on us if she had been here." ${ }^{39}$

\section{East New Jersey}

The first Scottish voyage to East New Jersey was sponsored by a group consisting of eleven proprietors and investors in the colony. Among them was the prominent Scottish Quaker, and governor of the colony, Robert Barclay of Ury and three prominent figures in the Restoration government of Scotland: James Drummond, $4^{\text {th }}$ Earl of Perth; his brother John Drummond of Lundin (later $1^{\text {st }}$ Earl of Melfort); and George Mackenzie, Lord Tarbat (later $1^{\text {st }}$ Earl of Cromarty). ${ }^{40}$ The vessel commissioned was the Exchange of Stockton, James Peacock master, which set sail from Aberdeen on 31 August 1683 with merchandise to be traded and supplies and livestock to be used by the proprietors' agents. ${ }^{41}$ A list from 1684 names twenty-five indentured servants who were likely transported to the colony by the Scottish proprietors on the Exchange..$^{42}$ Another, which may include women and children who were omitted from the 1684 list, refers to forty-seven servants sent to the colony by the Scottish proprietors in $1683 .{ }^{43}$ Including family members of the agents sent by the Scottish proprietors (twelve) and individuals sent on the personal accounts of Arent Sonmans (fifteen) and William Dockwra (twentythree), the total number of emigrants on the Exchange was about one hndred. ${ }^{44}$

As far as can be determined, four vessels departed Scotland for East Jersey in 1684. Two are emphasised in the promotional literature for the colony, though they are not named. For example, a 1685 promotional tract states that "There went in July last, 1684 a vessel from Leith with 160 passengers, or thereby; an other from Montrose with 130 to East-New-Jersey." ${ }^{45}$ An entry for "the Thomas and Benjeman of London Thomas Person m[aste]r for East new Jearsie in America" in the Montrose customs books reveals the identity of the vessel that transported 130

\footnotetext{
39 Dunlop to Montgomerie, 21 October 1686, NRS, GD3/5/775.

40 William A. Whitehead, et al., eds., Documents Relating to the Colonial History of the State of New Jersey (DRCHNJ), $1^{\text {st }}$ ser., 42 vols. (1880-1949), 1: 464-469.

${ }^{41}$ The agents were David Barclay (brother of Robert), John Reid, John Hanton, and Peter Watson. Ibid.; Aberdeen entry book: exports, 16-18 August 1683, fol. 8, NRS, E72/1/10.

42 "The names of such p[er]sons as were imported into this province," 5 December 1684, fol. 155 , New Jersey State Archives (NJSA), SSTSE023.A(EJ).

43 George J. Miller, ed., The Minutes of the Board of Proprietors of the Eastern Division of New Jersey from 1685 to 1705 (Perth Amboy: Board of Proprietors of the Eastern Division of New Jersey, 1985), 147, 157-158.

44 Sonmans was a Dutch merchant resident in Scotland and Dockwra was a London merchant; both were East Jersey proprietors. "The names of such p[er]sons," fol. 155, NJSA, SSTSE023.A(EJ); Land warrant for William Ridford, 26 September 1685, fol. 85, NJSA, PEASJ003.O(EJ); DRCHNJ, 13: 124, 21: 59 .

45 A Brief Advertisement Concerning East-New-Jersey, in America (Edinburgh, 1685), sig. A[1]r.
} 
passengers. ${ }^{46}$ The number of " 130 souls besids sea men" is corroborated in a letter written by one of the passengers. ${ }^{47}$ Many of the passengers on the Thomas and Benjamin were indentured servants belonging to Scottish investors and planters. For example, David Mudie sailed on the vessel with thirteen servants. ${ }^{48}$ The Thomas and Benjamin was in Leith in May where it was loaded with a cargo of clothing and meal and then sailed to Montrose where it was loaded with textiles, millstones, and additional clothing. ${ }^{49}$ It proceeded to Killybegs, Ireland before sailing to East Jersey, where it arrived by October. ${ }^{50}$ Though charged with violating the English Navigation Acts, the case was dismissed when the plaintiff did not appear in court. ${ }^{51}$

It can be determined that the Shield of Stockton was the "vessel from Leith with 160 passengers." There is an entry in the Leith customs books for "the Sheild of Stocktone Patrick Falconer mer[chan]t" from 11 July 1684 and Patrick Falconer was in East Jersey by the end of October $1684 .{ }^{52}$ Additionally, there is a headland record for Peter Bury, who was transported to East Jersey as "a servant to Gawen Drummond in a ship called the Shield belonging to Stockden in Yorkshire in old England Daniell Towes master to the s[ai]d ship arrived in Pautuxon upon the twenty nynth day of September anno domini one thousand six hundred eighty four." 53 Arrival at the Patuxent River in Maryland is consistent with reports of the vessel carrying 160 passengers, which sailed up "Chessapeik bay, up through all Virginia up to Maryland, where we landed at the place where our ship was bound to take in her tobacoo, for her homeward loading." The vessel was "disabled" in Maryland and the journey to East Jersey needed to be completed overland or on sloops.$^{54}$ Lastly, the Scottish proprietors made arrangements with David Towes presumably a relation of Daniel Towes, master of the Shield - "for a freight of his ship" in May $1684 .{ }^{55}$ An example of a planter who sailed on the Shield is Thomas Gordon, who brough his wife, four children, and nine indentured servants with

\footnotetext{
46 Montrose entry book: exports, 30 June-3 July 1684, fol. 15, NRS, E72/16/13.

47 Scott, Model of the Government, 236.

48 He also brought four of his children with him. List of children and servants imported by Mudie, November 1684, fol. 196, NJSA, SSTSE023.A(EJ).

49 Leith entry book: exports, 26 May 1684, fol. 6, NRS, E72/15/28; Montrose entry book: exports, 30 June-3 July, fol. 15, NRS, E72/16/13.

50 Scott, Model of the Government, 202, 260; Miller, Minutes of the Board of Proprietors, 73.

51 Preston W. Edsall, ed., Journal of the Courts of Common Right and Chancery of East New Jersey, 1683-1702 (Philadelphia: American Legal History Society, 1937), 134-135, 192-194.

52 Leith entry book: exports, 11 July 1684, fol. 8, NRS, E72/15/28; David Barclay and Arthur Forbes, An Advertisement Concerning the Province of East-New-Jersey in America (Edinburgh, 1685), 18-19.

53 Deed from Bury to Archibald Campbell, 20 October 1688, fol. 132, NJSA, SSTSE023.D(EJ).

54 Scott, Model of the Government, 240.

55 Extracts from Robert Barclay's journal, fols. 12, 14, 16-17, 22, NJSA, S0004001.
} 
him. ${ }^{56}$ The vessel's cargo included textiles, clothing, and nails. ${ }^{57}$

Less is known about the other two vessels that transported Scots to East Jersey in 1684. Writing of his arrival in Perth Amboy at the end of September 1684, John Campbell reported that "Lockharts ship arrived the next day, which made us very throng. ${ }^{"}{ }^{8}$ In all likelihood this was a reference to George Lockhart, who had resided in New York and New Jersey, published a letter promoting the Scottish effort in East Jersey in 1683, and became more deeply involved in the venture over the following years. ${ }^{59} \mathrm{He}$ acquired at least twelve prisoners from the privy council to transport to America "in his ship from Leith" in 1683, but the name of the ship is not given and the voyage was delayed. ${ }^{60}$ One of the individuals he acquired from the privy council, William Laing, was transferred to Robert Barclay of Ury in Montrose on 27 June 1684. ${ }^{61}$ Thus, we have evidence for Lockhart and the eleven remaining prisoners as potential passengers on "Lockharts ship." It is likely that there were more than twelve passengers, but there is no evidential basis for an estimate.

Very little is known about David Toschach, Lord Minevard's voyage to East Jersey in 1684. On 4 March 1684, Robert Barclay referred to a vessel "that is goeing from Glasgow with Manyvard" to East Jersey. ${ }^{62}$ In May, Minevard was granted permission by the privy council to transport three fugitives being held in Stirling to East Jersey ${ }^{63} \mathrm{He}$ was in Perth Amboy by October and, without additional evidence, it is presumed that he and the three individuals he acquired from the privy council travelled there on a vessel from Glasgow. ${ }^{64}$

It appears that another group of Scots - the Quaker schismatic George Keith, his wife and two daughters, two servants, and an apprentice - also departed for East Jersey in 1684. They, however, wintered in Barbados and did not arrive in East Jersey until February $1685 .{ }^{65}$ Instructions sent from the proprietors to the deputy governor in November 1684 refer to a document "which was sent by George Keith, upon the Blossom, Richard Martin Master." ${ }^{66}$ No additional evidence relating to

\footnotetext{
56 "Imported by Thomas Gordon into the Province of East New Jersey," October 1684, fol. 187, NJSA, SSTSE023.A(EJ).

57 Leith entry book: exports, 11 July 1684, fol. 8, NRS, E72/15/28.

58 Barclay and Forbes, An Advertisement, 2.

59 George Lockhart, A Further Account of East-New-Jarsey By a Letter Write to One of the Proprietors Thereof, by a Countrey-man, who has a great Plantation there (Edinburgh, 1683); DRCHNJ, 1: 430-431, 21: 53, 92-93, 95, 140, 174, 223; Miller, Minutes of the Board of Proprietors, 63, 131, 224-225; RPCS, $3^{\text {rd }}$ ser., 8: 235.

$60 \quad R P C S, 3^{\text {rd }}$ ser., 8: 235, 516-520, 709-710.

61 Barclay's journal, fol. 15, NJSA, S0004001.

62 E. Dunbar Dunbar, Social Life in Former Days, $2^{\text {nd }}$ ser. (Edinburgh, 1866), 105.

$63 \quad R P C S, 3^{\text {rd }}$ ser., 8: 514-515, 9: 210.

64 Barclay and Forbes, An Advertisement, 2-3.

65 DRCHNJ, 21: 69; Scott, Model of the Government, 225; Miller, Minutes of the Board of Proprietors, 117.

66 DRCHNJ, 1: 480.
} 
the Blossom or the journey of these emigrants has been discovered, though it is possible that they had originally planned to travel to East Jersey via Barbados on the Orange Tree. ${ }^{67}$

Scots oversaw two additional voyages to East Jersey in 1685. In 1686, Robert Barclay wrote that his brother David departed "about ye end of August last past aboard ye ship called ye America of Stockton Captain Vivers master bound from ye road of Aberdeen in Scotland to New East Jersey." ${ }_{68}$ Appearing as the America Merchant of Stockton, it is recorded as departing Aberdeen on 26 August 1685 with a cargo of textiles and clothing with David Barclay serving as merchant. ${ }^{69}$ The fact that David Barclay was aboard strongly suggests that it was on this vessel that his brother Robert's twenty-three servants were transported in $1685 .^{70}$

There is also reason to believe that it was the America on which Lord Neill Campbell, his son Archibald, and their company of fifty-three others made their journey to East Jersey in $1685 . .^{71}$ In addition to David Barclay, the vessel was freighted by Robert Blackwood, who was Campbell's partner in the East Jersey venture, having a half interest in all the goods Campbell transported to America. ${ }^{72}$ This fact indicates that the Campbell contingent was transported on the America. That it was said on 3 September 1685 that Campbell set sail "about a month ago" does not undermine this suggestion. ${ }^{73}$ Though the America departed Aberdeen on 26 August, it appears to have departed Leith on either 5 or 13 August with a cargo of textiles, clothing, knives, and meal. ${ }^{74}$ There is also evidence that Charles Gordon and his servant John Dickson embarked in Leith to go to East Jersey on the America. ${ }^{75}$

The best known Scottish voyage to East Jersey is that of the 350-ton Henry and Francis of Newcastle, Richard Hutton master. It was organised by the dissenting laird George Scott of Pitlochie, who had previously been involved in the Carolina venture. ${ }^{76}$ The Scottish privy council granted about one hundred prisoners, mostly doctrinaire Presbyterians who refused to take the oath of allegiance, to Scott to

\footnotetext{
67 Joseph R. Klett, "Transcription of the Minutes of the Proprietors of the Province of East Jersey, 1682-1684," Journal of the Rutgers University Libraries, 63 (2007), 67.

68 Conveyance from Robert Barclay to John Barclay, 8 March 1686, fol. 109, NJSA,SSTSE023.G(EJ).

69 Aberdeen entry book: exports, 26 August 1685, fol. 21, NRS, E72/1/13.

$70 \quad R P C S, 3^{\text {rd }}$ ser., 11: 127, 130-131.

71 Lord Neill Campbell was younger son of the Marquis (and $8^{\text {th }}$ Earl) of Argyll. When his father was executed in 1661 for having supported Cromwell, the marquisate was attainted. His brother became the $9^{\text {th }}$ Earl of Argyll. He was executed as a rebel about two months before the departure of the America. List of persons imported by Campbell, December 1685, fol. 225, NJSA, SSTSE023.A(EJ); Campbell and Robert Blackwood to James Campbell, [1689?], NRS, GD50/186/65 (Item 7); Fryer, "Robert Barclay of Ury," 8-10.

72 Barclay and Forbes, An Advertisement, 22; Instructions from Campbell, [1686?], NRS, GD50/186/65 (Item 2).

73 MacLeod, Journal, 154.

74 Leith entry book: exports, 5-13 August, fols. 18-19, NRS, E72/15/32.

75 Dunbar, Social Life, 113-114.

76 Fryer, "Robert Barclay of Ury," 8-12.
} 
be transported to East Jersey. ${ }^{77}$ In addition to prisoners, Scott's voyage included people "who voluntarily offered themselves to go abroad from the Kingdom of Scotland." ${ }^{\prime 78}$ Among the voluntary emigrants were James Dundas, brother of the laird of Arniston, the merchant Alexander Adam, and the apothecary James Hutchison. The merchant James Armour was able to go as a free man as a condition of his release from the Glasgow tolbooth. ${ }^{79}$ Including prisoners and volunteers, we have the names of 122 people who sailed on Scott's voyage to East Jersey. It is likely that not all the names have come down to us and the number of two hundred people transported on the Henry and Francis - given in a contemporary account - appears plausible.$^{80}$ They departed Leith around 5 September 1685 with an exceptionally large cargo that included textiles, clothing, buttons, and nails. ${ }^{81}$ The expedition was disastrous as approximately sixty of those on board died from illness, including Scott and his wife Margaret. The survivors arrived in Perth Amboy around 7 December, but many of them moved to settle in New England before returning to Scotland after the Glorious Revolution in 1688-1689..$^{82}$

The activity of the Scottish proprietors and investors who remained in Scotland decreased significantly in the following years, especially as East Jersey temporarily ceased to be a proprietary colony when it was incorporated into the Dominion of New England in $1688 .{ }^{83}$ The one vessel known to have been sent to the colony by Scottish investors during the Dominion period was David Mudie's Dutch-built vessel the Unity, which was condemned in the Middlesex court of common pleas for breaking the Navigation Acts. The vessel had come from Montrose with fifty servants. $^{84}$

\section{Conclusion}

Four hundred and ninety-nine people have been individually identified as emigrating to East Jersey between 1683 and 1685 as part of my ongoing research. Not all names have come down to us and at least 693 people (including those who died en route) were transported to East Jersey between 1683 and 1685 on eight different vessels by Scots and their associates. An additional fifty were transported in 1688 , making the total at least 743 for 1683-1688:

\footnotetext{
$77 R P C S, 3^{\text {rd }}$ ser., 10: 79, 11: 137, 148-149, 154-159, 162-168, 173, 475-476, 13: 125; MacLeod, Journal, 153-154; Robert Wodrow, The History of the Sufferings of the Church of Scotland, from the Restauration to the Revolution, vol. 2 (Edinburgh, 1722), 565-569.

78 Wodrow, The History of the Sufferings, 566.

79 DRCHNJ, 21: 70, 93, 125, 23: 408; RPCS, $3^{\text {rd }}$ ser., 10: 206.

80 Deed to Scott, 28 July 1685, fol. 384, NJSA, SSTSE023.A(EJ).

81 Leith entry book: exports, August-September 1685, fols. 19-23, NRS, E72/15/32.

82 "Acc[om]pt of Pitlochies Ship \& Death," 11 May 1686, fol. 226r, NLS, Wod.Qu.XXXVI; Wodrow, The History of the Sufferings, 565-569; Edsall, Journal of the Courts, 210-211.

83 Pomfret, The Province, 266-267.

${ }^{84}$ Edsall, Journal of the Courts, 136-137.
} 


\begin{tabular}{|l|l|}
\hline Place and Approximate Date of Departure & Vessel (approximate number of settlers) \\
\hline Aberdeen, 31 August 1683 & Exchange of Stockton (100) \\
\hline Montrose, 3 July 1684 & Thomas and Benjamin of London (130) \\
\hline Leith, 11 July 1684 & Shield of Stockton (160) \\
\hline Leith, July or August 1684 & George Lockhart's ship (12) \\
\hline Glasgow, between July and September 1684 & Unknown vessel (4) \\
\hline Unknown, 1684 & Blossom (7) \\
\hline Aberdeen, 26 August 1685 & America/America Merchant of Stockton (80) \\
\hline Leith, 5 September 1685 & Henry and Francis of Newcastle (200) \\
\hline Montrose, 1688 (before September) & Unity (50) \\
\hline
\end{tabular}

Meanwhile, seven vessels with a least some connection with the Scottish colonisation effort in Carolina had plans to sail to that colony between 1682 and 1686. The number of would-be settlers carried on these vessels was at least 470 and possibly in the range of six hundred or more:

\begin{tabular}{|l|l|}
\hline Place and Approximate Date of Departure & Vessel (approximate number of settlers) \\
\hline Glasgow, 16 October 1682 & James of Irvine (0) \\
\hline Gourock, 21 July 1684 & Carolina Merchant of Glasgow (148) \\
\hline Leith, 14 August 1684 & Alexander of Inverkeithing (150) \\
\hline Glasgow, 29 August 1684 & Charles of Glasgow (unknown) \\
\hline Ayr, 19 August 1684 & James of Ayr (140) \\
\hline Londonderry, 1685 (before May) & Abercorn (30-80) \\
\hline Kelburn, 4 March 1686 & Richard and John (unknown) \\
\hline
\end{tabular}

The James of Irvine is not known to have transported permanent settlers and three of the vessels - the Charles, the James of Ayr, and the Richard and John never made it to Carolina. Furthermore, many of the emigrants who did make it died shortly thereafter and others did not proceed to the Scottish settlement in Port Royal. The large-scale ambitions of the venture were undercut by these issues.

As this account shows, the Scottish colonising voyages of the $1680 \mathrm{~s}$ underpinned serious and ambitious attempts to establish Scottish settlements in Carolina and East New Jersey. Details relating to the vessels, the place and time of their departures, and their passengers and cargos can serve as a starting point for additional research on the topic. 